\title{
The Effect of Gender Inequality on Economic Growth in West Africa
}

\author{
Joseph Agyina* Prof. Anthony Kofi Osei-Fosu ${ }^{2}$ \\ School of Economics \\ Kwame Nkrumah University of Science and Technology (KNUST), Kumasi, Ghana
}

\begin{abstract}
Using panel data, this study examined how gender inequality affects economic growth in West Africa. The paper used data from 1997 to 2017 on GDP growth and three gender indicators. Nine countries in West Africa made up the study. The generalized method of moment (GMM) was the estimator used in estimating dependent variable and independent variables of the study. The dependent variable was GDP growth acting as a proxy for economic growth. The independent variables comprised of gender parity of primary school enrollment between female and male, labour participation ratio of female to male and gender inequality index (GII). The result of the study showed that at $1 \%$ level of significant, labour participation rate of female to male, gender parity in school enrollment and gender inequality statistically affect economic growth in West Africa. However, the outcome showed that whereas gender inequality adversely affects economic growth, increase in both participation rate of female and gender parity of school enrollment positively influence growth in West African economy. Population growth which was one of the controlled variables also showed a significant effect on economic growth. The study recommends that further studies should be conducted in area of job segregation and labour differences.
\end{abstract}

Keywords: Gender Inequality Index (GII), Labour, femal, male, Economic

DOI: $10.7176 / \mathrm{JEP} / 11-24-08$

Publication date: December $31^{\text {st }} 2020$

\section{Introduction}

Economists believe that fixed capital, human capital and labor force are the most important factors which can affect economic growth. However, one key variable to drive economic growth is gender equality. Thus, the need for gender equality is no more a moral ideology but an economic one. The introduction of the Sustainable Development Goals (Goal 5), has amplified how gender inequality is impeding human capital in the world as most countries especially in Africa are far away from achieving the mid mark of gender equality. According to the International Labour Organisation (ILO) (2017), for higher economic growth and improved human capital globally, then the world must ensure the full participation of female in the production of world's goods and services, as total inclusion is the only approach in achieving sustainable growth globally.

UN report in 2016, revealed that out of the total labour force as at 2016, men were 700 more than women in the labour market. The report indicated that even with the females employed, they were likely to receive wages lesser than their male counterpart in the same work field and are most often working in poor environmental condition with little or no future for career advancement, which does not only negatively affect the economic wellbeing of the women, but also that of the country (UN, 2016). Simple Efficiency Argument theory suggests that growth can only be achieved when there is perfect use of factors of production (male and female). With average gender inequality in West Africa being about 0.61 and a continuous low economic growth (2.8) (IMF 2019 \& World Bank 2018), then there is the need to consider whether gender inequality has influence in the economic growth in the region.

\subsection{Statement of Problem}

Economic growth remains the key target of successive governments in Ghana as well as that of West Africa. Economists have propounded that for economic growth to be realized, there should be efficiency. Efficiency cannot be achieved, when there is inappropriate and ineffective use of factors of production. Labour force (humans) remain part of production process yet, there still remain unequal distribution of gender groups in the employment in Ghana and other West African countries. Africa as a whole, tends to prefer male to female in almost every social context. Relative to other western countries, West African countries tend to grow at a lower rate (World Economic Forum 2018).

Sustainable Development Goal 5 which tends to promote gender equality in all facets of life is yet to be realized by West African countries as there seems to be several obstacles faced by women in the employment structure and other sector of the economy. The sub-region is associated with gender inequality index of 0.61 , indicating high gender inequality as at 2018 (Word Economic Forum 2018). A study conducted by the IMF in 2016 indicated that most countries in the African continent experience huge gender inequality despite effort in made in gender parity in recent period. With low education opportunity for females and lack of opportunity of job access and empowerment to women, gender inequality tends to be high in West Africa. As the world aims at 
reducing gender inequality and improve economic growth, it begs to ask why most West African countries are failing to achieve the SDG 5.

The sub-region tends to have low economic growth and high gender inequality relative to western countries and almost every year, governments in the sub-region fail to achieve its estimated economic growth (Hakura, 2016). This therefore generates the argument of whether inequality can influence economic growth. Report on Gender inequality index (GII) from the IMF and economic growth from the World bank give the indication that countries with high gender inequality gap tends to have low economic growth as compared to countries with low inequality gap. Several studies (Ostry, Berg, \& Tsangarides, 2014; O’Reilly, 2015; Kis-Katos, Pieters, \& Sparrow, 2018; IMF 2019) have also indicated how high gender equality gap tends to have a negative impact on economic growth of a country. However, West African countries are yet to have its share of literature of impact of gender equality to the economy. Current gender inequality ratio in Ghana is about .55 that of Nigeria and Ivory Coast are .51 and .67 respectively. There is therefore the need to consider whether gender inequality in West African countries have any effect on the economic growth in the region (IMF 2019).

In addition to the already stated facts, according to a study conducted by the Ostry, Berg, and Tsangarides (2014), whereas countries have been able to make progress on gender inequality, West African region is slower when it comes to such agenda, yet economic progress of countries within the sub-region still remains relatively low. The question that begs to be answered is does gender equality influence economic growth of countries? Also, does gender parity in education affect economic growth? Does unequal gender in employment influence economic growth? With the target of high economic growth in most West African countries and the rise in the campaign for gender equality in employment, health, education and empowerment in the sub-region, there is the need to identify why this phenomenon still persist despite being the agenda of most government (IMF 2017; World Bank 2017). It therefore becomes imperative to identify whether improving the gender equality gap can improve the economic growth of West African countries. In addition to this, most studies conducted in this area tend to focus on developing countries rather than being specific on West African countries, as they share similar characteristics (Schieder, Jessica and Elise Gould, 2016; Kis-Katos, Pieters, \& Sparrow, 2018; O’Reilly, 2015; Ostry, Berg, \& Tsangarides, 2014). Thus, conducting this study gives a clear reflection of the impact of gender inequality on economic growth in West Africa and fills the literature gap on this phenomenon. In this regard, it is of much relevant to evaluate the effect of gender inequality on economic growth in West Africa.

\subsection{Objective of the Study}

Generally, the study examined the effect of gender inequality on economic growth in West Africa.

Specifically, the study sought to;

1. Evaluate the relationship between gender inequality indicators and economic growth in West African countries

2. Examine the effect of gender parity in school enrollment on economic growth

3. Examine the effect of Labor Force Participation Rate of Females on economic growth

4. Examine the effect of gender inequality on economic growth in West Africa.

\subsection{Hypothesis}

1. $H_{0}$ Gender parity of school enrollment has no significant effect on economic growth in West Africa

$H_{a}$ : There is a positive significant effect of gender parity in school enrollment on economic growth in West Africa

2. $H_{0}$ : There is no significant effect of labour force participation rate of females on economic growth in West Africa

$H_{a}$ : There is a positive significant effect of labour force participation rate of females on economic growth in West Africa

3. $H_{0}$ : Gender inequality has no significant effect on economic growth in West Africa

$H_{a}$ : Gender inequality has negative significant effect on economic growth in West Africa

\subsection{Justification of the Study}

With most countries including West African countries trying to attain the Sustainable Development Goals, it raises questions as to why certain areas (gender inequality gap and economic growth) that need to be improved still remain relatively the same. For the growing knowledge and debate about gender inequality in countries like Ghana, Nigeria and other West African countries, it therefore gives the credence about the relevant of the study to the region. As such the need for this study cannot be overemphasized, with gender inequality and slow GDP growth in this region raises question on the impact and persistent of these concepts growth of the region. This tends to inform policy making to foster inclusive and growth that aims at achieving the Sustainable Development Goals (SDGs). 


\subsection{Scope of the Study}

The study was focused on the relationship between gender inequality and economic growth. It covers the factors that make gender inequality persistent in West Africa. It also considered the whether gender disparity influences economic growth of West African region. The variables included were gender parity index, female ratio in the labour force and inequality indicator that measured gender inequality whereas gross domestic growth as a proxy for economic growth in the study. The geographical scope of the study is West African.

\subsection{Limitation of the Study}

One significant limitation to the study was data among the countries in West Africa. 16 countries were initially sampled for the study, however, due to lack of data on gender inequality, 9 countries were used to for the analysis.

\subsection{LITERATURE REVIEW}

This chapter focuses on the theoretical and empirical review of the study. It takes into consideration the various concept, empirical and theories of gender inequality and economic growth.

\subsection{Conceptual Literature}

The section tends to define the following concepts; economic growth, gender inequality, school enrolment, gender gap in school enrolment and gender.

\subsubsection{Economic Growth}

According to Haller (2012), economic growth is the process of improving the sizes of national economies, the macro-economic indications, mostly the GDP per capita, in an ascendant but not necessarily linear direction, with positive effects on the economic-social sector, while development shows us how growth impacts on the society by increasing the standard of life. In Haller (2012) view, typologically, in one sense and in the other, economic growth can be: positive, zero, negative. Positive economic growth is recorded when at the end of the year, the average trend of economic indicators shows higher results relative population growth. Also, if the within a year, the average economic growth of the macro-economic variables particular, GDP, are equal to that of the population growth then there is zero economic growth for that economy. However negative economic growth is realized when the average macro-economic indicators appear to be lower that of the population growth of the economy. In essence, to achieve economic growth is based on the efficient use resources available and the increase in the capacity of country's production. Thus, economic growth promotes the efficient allocation of capital to the entire population of a country.

\subsubsection{Gender}

UNESCO (2014), defined gender as the duties and roles assigned to male and female which are created by families, cultures and the society of a country. Thus, being a male or a female according to the report of UNESCO (2014), comes with its expected behaviour and attitude that each individual must live by it. The concept of gender is vital because, it applies to social analysis, it reveals how women's subordination (or men's domination) is socially constructed. As such, the subordination can be changed or ended. It is not biologically predetermined nor is it fixed forever (UNESCO, 2014).

\subsubsection{Gender Inequality}

According to UNESCO (2017), Gender inequality is basically the marginalization of certain groups of people thorough social and economic stratification and socialization. UNESCO in their report in 2015 revealed that there are gender differences in terms economic wellbeing and social wellbeing irrespective of a person's socioeconomic class. The degree of gender differences however, vary from state to state and across time. Gender inequality per several studies tends to be in favour of males in the context of economic, social and political position. For more than two decades, the objective of reducing gender inequality has been the center of focus for most countries as well as international organisations.

\subsubsection{Gender Equality in Education}

This phenomenon indicates the equal opportunity for both male and female in education all facets of the educational system. The realization of equality between female and male students in education fall on the basis of political, cultural social and economic framework. A global trend analysis by UNESCO indicated in their report on adult literacy in 2017 revealed that in Sub Sahara Africa, adult literacy rate is relatively high. They further reported that what makes the phenomenon less encouraging is the gap between male and female. According to Sossou (2018), while education for everyone remains a major concern in most West African countries, the role of gender education on economic growth still remains untapped. As at 2017 , men were more than $5 \%$ educated than women (UNESCO, 2017). According to Lagarde (2018), inequality in education influences the average human capital and reduces growth. 


\subsubsection{Definition of Labour participation rate of female to male}

The study explained the labour participation rate of female to male as gender parity in employment, female to male labour ratio, as well as labour ratio of female to male. These concepts were used interchangeably in the study.

\subsubsection{Definition of Gender parity of school enrolment between female and male}

Gender parity of school enrollment between female and male was defined on gender in school enrollment, school enrollment ratio and the ratio of male to female in education.

\subsubsection{Theoretical Framework of the Solow-Growth model}

Robert Solow and Trevor Swan propounded the growth model in 1956. The model measures the growth of a nation using the production function of neoclassical theory and it only shows long run economic growth of a particular nation. According to the model, economic is a function of labour force, productivity and capital formation considers the long-run economic growth as a function of capital accumulation, labour (population growth) and productivity. Among various factors of production, the one that is of interest to the study is the labour factor. The model assumes that there is a relationship between labour and economic growth. Since this study considers how gender gap affects economic growth in West Africa, then labour in this market is of relevant to the study. The Model also assumes that there is a positive relationship between research and development and economic growth. As such the study tends to consider the gender parity in school enrollment and economic growth.

\subsubsection{Theoretical Framework of 2.2.4 Simple Efficiency Argument: Male and Female in economic Growth} Simple efficiency argument was propounded by Knowles et al (2002). The main concern of the theory is that in production, neither of the gender groups can be substituted for the other. The argument of the theory suggests that when perfect substitution is unachieved due to gender inequality, it results in misallocation of factors of production leading to negative effect on the economy. According to the theory, why gender inequality negatively affects the growth of the economy is based on two main grounds. The first is the fact that men and women are two distinct input among the factors of production for economic outcome in a nation. Whereas the second premise is of the fact that factors of production tend to have positive and diminishing marginal products. Knowles et al., (2002), made emphasis using Solo-neoclassical growth model to suggest that male and female education are imperfect substitutes in production.

Knowles et al., (2002) purported that if men are more educated than women, the appropriate approach to reduce the gender gap is to increase the participation of women in education while education of males remains constant. According to Knowles et al., (2002), this increases the average level of education in the economy leading to increase in the GDP growth as a result of gender parity that would be achieved. The theory however, indicated that female's output elasticity of education is larger than that of males. Their justification was based on positive externalities that are likely to be achieved out of female education. Thus, these externalities according to them include reduction in fertility and infant mortality, educated females improve the quality and quantity of their children's education. In this regard, when gender inequality in education is at the expense of females, per capita output in the long run reduces. The underlying argument of Knowles et al (2002) goes beyond education as it extends to health, employment and access to capital. Thus, the theory explains the link between gender inequality and economic growth of a country or region which fits the analysis of this study.

\subsection{Empirical Review}

A study by Yang et al, (2016), showed that dynamic models have the problem that gender gaps in wage and the subsequent gender gap in labor force participation are endogenous to economic growth. This is also evident in the work of Amin, Kuntchev, and Schmidt (2015) which had an endogenous impact on growth. In the study of Yang et al, (2016), it failed to consider capital formation as a factor to economic growth.

In addition, gender inequality in school enrolment is said to be an important component in gender inequality. However, several studies fail to consider such phenomena in addressing economic growth. For instance, works from Biswas et al (2015) and Smidcht (2015) failed to evaluate how gender gap in primary and secondary education could have different result on the growth of an economy. In relation to school enrollment as a factor to economic growth, some studies concluded that economic growth is not affected by school enrollment, and it makes that report unique to other studies (Cuberes and Teignier 2015; Esteve-Volart 2004) that tend to conclude that education influence economic growth.

On the basis of labour force, several studies conclude that increasing female labour participation tend to increase economic growth. Their argument reveals that when gender inequality gap is reduced in the area of labour force, it results in increase in economic growth of a region (Galor and Zeira 1993; Yang et al's 2016; \& Corak 2013). Despite several reports indicating the significance of gender parity of labour force in economic growth, the study of Al Rakhis (2015) and Cingano (2014), rather indicated that increasing the opportunities of males in labour market and education may generate huge economic growth in the economy. 
Several studies reviewed, tend to focus on different method of estimate. While some used OLS, others used Generalized Method of Moments (GMM) as the methodology for studies. Al Rakhis (2015) whose study outcome was different, adopted the OLS as methodology whereas Yang et al., (2016) used GMM for their study. In this regard, the current study also focuses on using the GMM as methodology to generate the outcome.

Finally, in reviewing the literature, several regions were considered, from the area of Middle East and North Africa (MENA) (Al Rahkis 2015), Europe, the work of Cuberes and Teigner (2015) and and EsteveVolart (2004), North and South America (Galor and Zeira 1999), and Sub-Sahara Africa (Yang et al's 2016). Also, there was a gap in the area of gender inequality on empowerment from literature reviewed, only two made mentioned of the gap in empowerment among the gender group. However, there was no exclusive literature in West Africa that considered gender inequality and economic growth. With West African countries having peculiar characteristics to which cannot be found in other African countries, it is imperative to conduct a study in the subject area that purposely focus on West Africa and how that outcome is different from other regions.

\subsection{RESEARCH METHODS}

This chapter focused on the methods and variables that were used in conducting the effect of gender inequality and economic growth in West Africa. It focuses on the research design, the model specification, method of estimation and sources of data.

\subsection{Model specification}

Economic growth is influence by several factors that are favorable and unfavourable to the economy. With the model being endogenous growth model, it therefore permits examining the various gender inequality indicators as well as other variables as controlled variables affect growth. In addition, for the study to be reliable and provide a valid relationship between the independent and dependent variable, some indicators were factored in the model. These indicators of the model include the gross domestic production growth rate, which is the dependent variable and served as a proxy for economic growth. The independent variables include, gross fixed capital formation, labour participation rate of female to male as a proxy for the ratio of female to male labour force. Also, the population growth of West African nations was included. Trade as percentage of GDP was also included as a proxy for trade openness. Gender inequality index and gender parity index of school enrollment were also part of the study. Among the independent variable, capital formation, population and trade openness were the controlled variables in the study.

Model 3.1 below, represents the linear regression for labour participation rates of female to male and economic growth (LF). It details the relationship that exists between labour participation rates of female to male and GDP growth (proxy of economic growth), where GDP growth was the dependent growth and labour participation rates of female to male being the independent variable. Model 3.2 provides the relationship between gender parity in school enrollment (independent variable) and economic growth (dependent variable). The last model which is Model 3.3 indicates the relationship between gender inequality and economic growth.

$G D P_{i t}=\beta_{0}+\beta_{1} K F_{i t}+\beta_{2} L F_{i t}+\beta_{3} P O P_{i t}+\beta_{4} O P E N+\beta_{5} G D P_{i t-1}+\varepsilon_{i t} \ldots \ldots \ldots . . .3 .1$

$G D P_{i t}=\beta_{0}+\beta_{1} K F_{i t}+\beta_{2} G P I_{i t}+\beta_{3} P O P_{i t}+\beta_{4} O P E N_{i t}+\beta_{5} G D P_{i t-1}+\varepsilon_{i t} \ldots \ldots \ldots . . .3 .2$

$G D P_{i t}=\beta_{0}+\beta_{1} K F_{i t}+\beta_{2} G I I_{i t}+\beta_{3} P O P_{i t}+\beta_{4} O P E N+\beta_{5} G D P_{i t-1}+\varepsilon_{i t} \ldots \ldots \ldots \ldots .3$

GDP is Real domestic product growth (Real GDP growth) as a proxy for economic growth; KF represents the gross capital formation; LF represents the labour participation rate of female to male; POP measures population growth; GPI represents the gender parity of primary school enrollment between male and female; GII is the Gender Inequality Index; OPEN represents trade openness, $\beta$ represents the parameter for each variable studied; $\varepsilon$ represents the error term.

\subsection{Estimation Technique (GMM)}

In this paper, the generalized method of moment was the estimator adopted to estimate empirical model. This estimator was adopted because dynamic panel data was used for the analysis of the study. This estimator is widely used because it is able to estimate endogenous indicators that are unobserved and can have effect in the model (Beck et al., 2000). With the study being dynamic panel in nature, then lagged dependent variables will appear as explanatory variables. This is because the lag of economic growth will influence the current economic growth, thus, creating the problem of endogeneity. In order to resolve this, the study adopted Generalized Method of Moments (GMM) to produce consistent parameter estimates for finite number of time periods.

\subsection{Sources of Data}

The section evaluates data used in the analysis of the study. The study considered 16 West African Countries all together for the study. However, due to lack of data from some West African countries, nine countries made up for the study. The data sampled considers the period from 1997-2017. GDP growth, gross fixed capital formation, gender parity index, labour force participation rate of female to male, trade as a percentage of GDP and Annual 
Population Growth are the data used for the analysis of the study from World Development Indicators (WDI), United Nations Development Programme (UNDP), IMF and the World Bank database.

\subsection{DISCUSSION AND FINDINGS}

This chapter presents the data of the study in the form of tables and chart. It also analyses the result computed on the bases of the dependent variable and the independent variables in the study.

\subsubsection{Relationship Between GII and GDP Growth in West Africa}

As said by Amadeo (2019), "GDP growth rate is the most important indicator of economic health. The result used scatter plot and line graph to provide relationship and direction of GDP growth and GII. The study outcome revealed that as GII falls, GDP growth in West Africa tends to rise, whereas when GII increases, all things being equal, GDP growth falls. Per the outcome of the study clearly shows a negative relationship between GII and GDP growth. The relationship is supported by correlation coefficient of -0.397 . Thus, the correlation coefficient indicates that there is a weak negative relationship between GII and economic growth in West Africa.

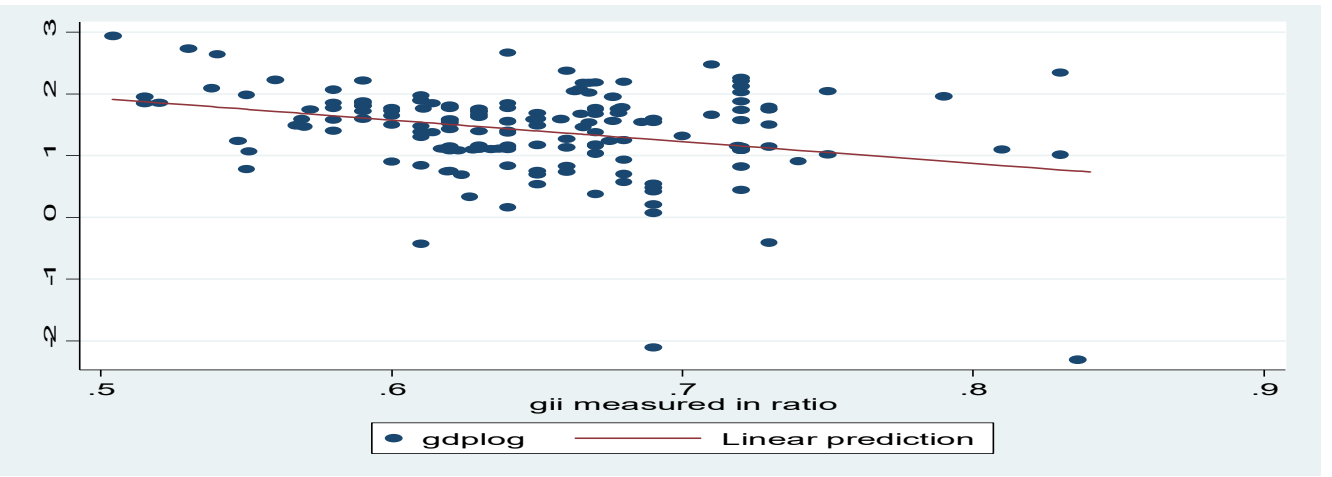

Source: Author 2019; Computation based on information from World Bank, IMF and HDI Figure 4. 1 GII And GDP Growth

\subsubsection{Labour Participation rate of Female to Male and GDP growth}

The labour participation rate of female to male also known as labour ratio between female and male has been a subject of debate in recent times in relation to gender equality in employment. Female to male labour participation rate has had relative steady trend as compared to gender inequality index. Figure 4.2 result shows a positive relationship between gender parity in employment and economic growth of West African countries. The correlation coefficient confirms the outcome with a value of 0.7155 . As such, there is a strong positive relationship between gender parity in employment and economic growth in West Africa.

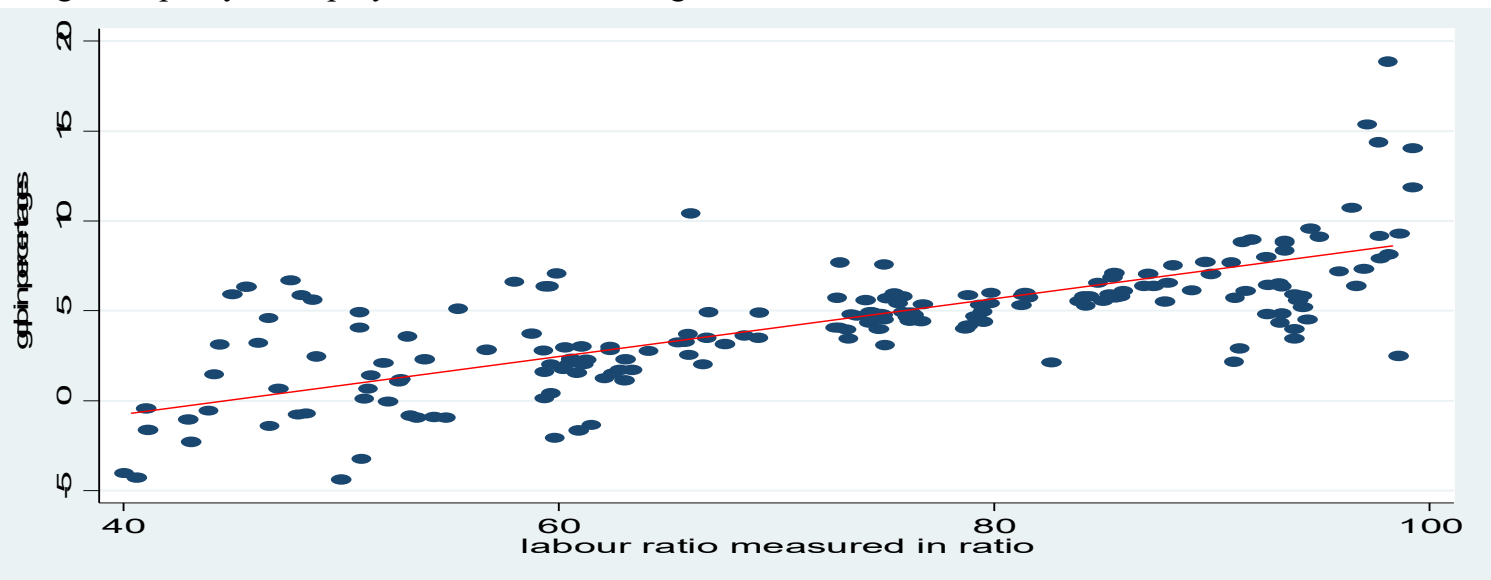

Source: Author 2019; Computation based on information from World Bank, IMF and HDI.

Figure 4. 2 Labour Ratio of Female to Male and GDP growth

\subsubsection{Relationship Between Gender parity index in School enrolment and GDP Growth rate}

Most studies have shown the relevance of gender parity index for gross enrollment and GDP growth. Figure 4.3 from of the scatter plot and line graph indicate a positive relation between gender parity in school enrollment and economic growth. Thus, as gender parity increases, economic growth of West Africa also increases. The result is also backed by the correlation coefficient of 0.6568 with relative strong correlation. 


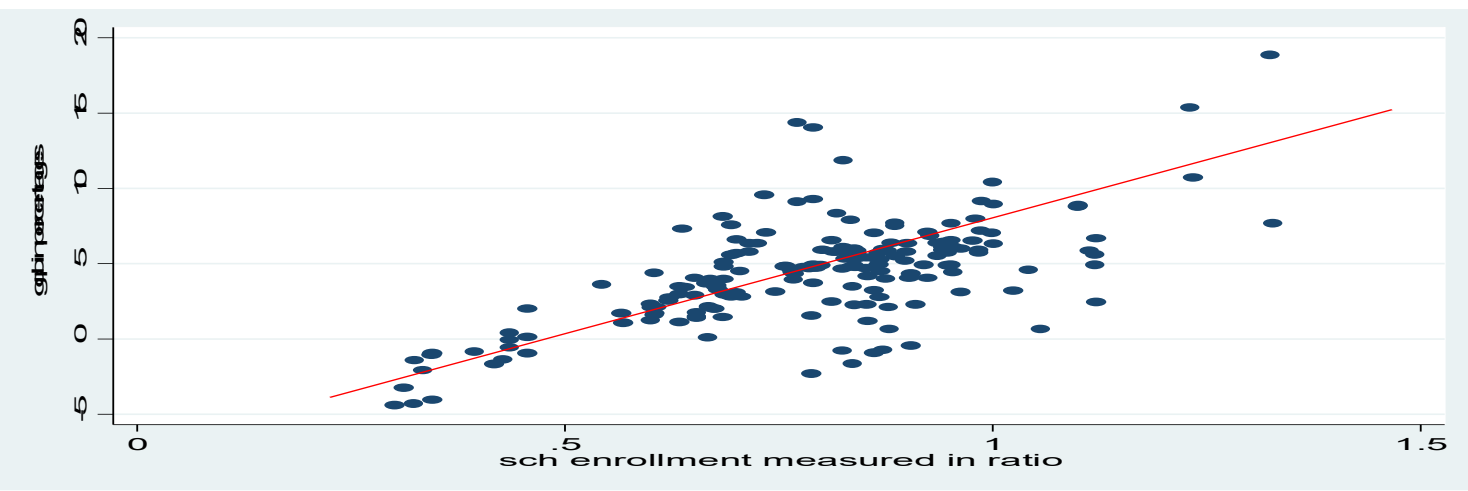

Source: Author 2019; Computation based on information from World Bank, IMF and HDI

Figure 4. 3 Gender parity index for gross enrollment ratio in primary education and GDP growth rate trend

\subsection{GMM Estimation of Gender Inequality and Economic Growth}

This section of the study provides an economic interpretation of the coefficients of the models estimated.

\section{Labour Force Participation Rate of Females to Male on Economic Growth (Model 1)}

Labour participation rate of female to male which serves as a proxy to gender gap to employment was of much relevance to the study as it looks at the gender differences in employment and how that contribute economic growth. From Model 1, Thus, the result shows a p-value of 0.001 and coefficient of 0.1148 . In essence, accounting for the effect of GDP growth in West Africa, the result clearly indicates that when the gender gap in employment is low it positively influences the growth of an economy. That is, if labour participation rate of female increases by 1 percent, then economic growth is expected to increase by 0.1148 percent.

\section{Gender Parity in School Enrollment on Economic Growth (Model 2)}

In testing for the effect of gender parity in school enrollment on economic growth, the p-value was 0.004 , the coefficient was 15.2454. The result therefore showed that the mean of gender parity in school enrollment in West Africa is positively related to economic growth, and statistically significant. In essence, gender parity in school enrollment positively affect the economic growth in West Africa.

\section{Gender Inequality on Economic Growth of West Africa (Model 3)}

Gender inequality index which examines the overall gap between men and women in four fundamental categories which are economic participation and opportunity, educational attainment, health and survival and political empowerment. Using GMM estimation, the result in model 3 showed a p-value of 0.002 , and a coefficient of 29.8799. From the output, it clearly revealed that gender inequality is negatively related to economic and statistically significant at $1 \%$ level of significant.

Table 4, 2 GMMEstimation of GDP Growth of Model 12 \& 3

\begin{tabular}{|c|c|c|c|c|c|c|c|c|c|}
\hline Variables & MODEL 1 & & & MODEL 2 & & & MODEL 3 & & \\
\hline & Coefficient & $\begin{array}{l}\text { Robust Std. } \\
\text { error }\end{array}$ & Prob. & coefficient & $\begin{array}{l}\text { Robust Std. } \\
\text { error }\end{array}$ & Prob. & coefficient & $\begin{array}{l}\text { Robust Std. } \\
\text { error }\end{array}$ & Prob. \\
\hline $\operatorname{GDP}(-1)$ & 0.133602 & 0.11454 & 0.907 & 0.023067 & 0.08895 & 0.795 & 0.0240 & 0.9787 & 0.806 \\
\hline POP & 2.6864 & 1.6476 & 0.103 & 25088 & 0.9163 & 0.006 & 4.1922 & 1.3311 & 0.002 \\
\hline $\mathrm{KF}$ & 0.0181 & 0.0580 & 0.754 & -0.0283 & 0.0549 & 0.606 & -0.0129 & 0.0656 & 0.844 \\
\hline OPEN & 0.0148 & 0.0266 & 0.577 & 0.0044 & 0.0300 & 0.883 & 0.00570 & 0.0337 & 0.866 \\
\hline LF & 0.1148 & 0.0354 & 0.001 & - & - & - & - & - & - \\
\hline GPI & - & - & - & 152454 & 52957 & 0.004 & - & - & - \\
\hline GII & - & - & - & - & - & - & -29.8799 & 9.7121 & 0.002 \\
\hline CONSTANT & -13.2069 & 63169 & 0.037 & -16.0733 & 5.4065 & 0.003 & 11.7073 & 6.0535 & 0.053 \\
\hline Hansen $z^{2}$ & 175511 & & & 177234 & & & 170.7296 & & \\
\hline test & [0.1075] & & & {$[0.1011]$} & & & {$[0.1551]$} & & \\
\hline$A R(2)$ & 1.6286 & & & 0.3530 & & & 1.0574 & & \\
\hline & [0.1034] & & & {$[0.7241]$} & & & [0.2903] & & \\
\hline Observations & 180 & & & 180 & & & 180 & & \\
\hline Number of id & 9 & & & 9 & & & 9 & & \\
\hline
\end{tabular}




\subsection{Discussion of Findings}

The result of the study from the labour participation rate of females to male on economic growth conforms to several studies Cuberes \& Teigner 2015; Biswas et al., 2015). For instance, both Elborgh-Woytek et al (2013) \& Stotsky (2006) reported from their study that gender disparity in economic participation tends to negatively affect GDP growth for every economy. The result of the study also supports the view of Biswas et al., (2015) who in their study concluded that greater presence of females in public service may change the composition of public expenditure in favor of health and education, which can raise potential growth over the medium to long run. Also, on gender parity, outcome is support of several literatures. For instance, the work of Olukayode \& Ayoola (2015) on gender disparity in school enrollment and development, showed the relevance of gender parity of school enrollment on growth. In another study by Manheim and Manheim, (2012), was also in support of the outcome of the study. They revealed that increase in gender parity in school enrollment creates avenues for innovations which in turn promote growth in the country (Mitra, Bang, and Biswas (2015). However, the study is inconsistent with the study of Cuberes \& Teigner (2015) \& Al Rahkis (2015), as their study showed that gender parity index in school enrollment had no effect on economic.

The Gender Inequality Index report of the study also confirms the work of Cuberes \& Teigner (2015). It is also in line with works of Elborgh-Woytek et al (2013); Biswas et al., (2015), Yang et al (2016) \& Gonzales et al (2015). The reports from these scholars showed that inequality contribute negatively to economic growth.

\subsection{Recommendation and Conclusion}

The economic growth of West African countries was modeled as a function of gender parity in school enrollment, labour participation rate, gender inequality, population growth, gross fixed capital formation and trade openness. Results from the labour participation rate of female to male, gender parity in school enrollment, gender inequality and population growth estimators' revealed statistically significant effect on economic growth. Whereas gender parity in employment, gender parity in school enrollment and population growth showed a positive effect on economic growth, gender inequality index revealed a negative effect on economic growth. However, gross fixed capital formation and trade openness showed no statistical effect on economic growth. The outcome of the study suggests the need for West African countries to focus on bridging the gap between male and female at the work place, health wise, education and other part of the economy that may negatively affect the growth of the region. The study recommends that in promoting the participation of females in the economy, there should be policies which promote gender parity among people working in legislative. This recommendation takes a queue from scholars that argue that for health and education to improve, there should be an increase female participation at the top position in public service to effect policy change (Biswas et al., 2015; Yang et al., 2018). Data on gender must be of key interest to policy makers in West Africa Further studies on how job segregation and gender differences influence economic growth in West African countries should be dealt into.

\section{Reference}

Mitra, A., Bang, J. T., \& Biswas, A. (2015). Gender equality and economic growth: Is it equality of opportunity or equality of outcomes?. Feminist Economics, 21(1), 110-135.

Galor, O. (2009). Inequality and economic development: An overview (No. 2009-3). Working Paper.

Hakura, M. D. S., Hussain, M. M., Newiak, M. M., Thakoor, V., \& Yang, M. F. (2016). Inequality, gender gaps and economic growth: Comparative evidence for sub-Saharan Africa. International Monetary Fund

Gonzales, C., Jain-Chandra, S., Kochhar, K., Newiak, M., \& Zeinullayev, T. (2015). Catalyst for change: Empowering women and tackling income inequality. FMI. Retrieved from: http://www.imf.org/external/pubs/ft/sdn/2015/sdn1520.pdf. Accessed on February 2019

Elborgh-Woytek, M. K., Newiak, M. M., Kochhar, M. K., Fabrizio, M. S., Kpodar, M. K., Wingender, M. P., ... \& Schwartz, M. G. (2013). Women, work, and the economy: Macroeconomic gains from gender equity. International Monetary Fund.

Cuberes, D., \& Teignier, M. (2015). How costly are labor gender gaps? Estimates for the Balkans

Stotsky, M. J. G. (2006). Gender and its relevance to macroeconomic policy: A survey (No. 6-233). International Monetary Fund

Bertay A. C , Dordevic L. \& Sever C. (2018). Gender Inequality and Economic Growth: Evidence from IndustryLevel Data

Esteve-Volart, B. (2004). Gender discrimination and growth: Theory and evidence from India.

Al Rakhis, M. (2015). Impact of Gender Inequality on Economic Growth in the Arab Region.

Galor, O., \& Zeira, J. (1993). Income Distribution and Macroeconomics. The review of economic studies, 60(1), 35-52.

Amin, M., Kuntchev, V., \& Schmidt, M. (2015). Gender inequality and growth: the case of rich vs. poor countries. The World Bank.

Knowles, S., Lorgelly, P. K., \& Owen, P. D. (2002). Are educational gender gaps a brake on economic 
development? Some cross-country empirical evidence. Oxford economic papers, 54(1), 118-149.

UNICEF (2014). Progress on Gender Equality Globally.

UNICEF (2017). Making Education a Priority in the Post-2015 Development Agenda. Report of the Global Thematic Consultation on Education in the Post-2015 Development Agenda.

Haller, A. P. (2012). Concepts of economic growth and development challenges of crisis and of knowledge. Economy Transdisciplinarity Cognition, 15(1), 66.

Ostry, J. D., \& Berg, A. (2011). Inequality and Unsustainable Growth; Two Sides of the Same Coin? (No. 11/08). International Monetary Fund.

Schieder, Jessica and Elise Gould, (2016). "Women's work" and the Gender Pay Gap: How Discrimination, Societal Norms, and Other Forces Affect Women's Occupational Choices - and Their Pay, Economic Policy Institute.

Kis-Katos, K., Pieters, J., \& Sparrow, R. (2018). Globalization and social change: Gender-specific effects of trade liberalization in Indonesia. IMF Economic Review, 66(4), 763-793.

O'Reilly, J., M. Smith, S. Deakin and B. Burchell, (2015). "Equal Pay as a Moving Target: International Perspectives on Forty-Years of Addressing the Gender Pay Gap", Cambridge Journal of Economics, vol. 39, no. 2, pp. 299-317

International Labour Organization (2017). Towards a Better Future for Women and Work: Voices of Women and Men

International Monetary Fund (2013). Women, Work and the Economy: Macroeconomic Gains from Gender Equity, IMF Staff Discussion Note 13/10 International Monetary Fund (2017). Annual Report

World Bank. (2017). World Bank country and Gender Disparity in Education.

World Economic Forum (2018). The Global Competitiveness Report 2018.

Hakura, M. D. S., Hussain, M. M., Newiak, M. M., Thakoor, V., \& Yang, M. F. (2016). Inequality, gender gaps and economic growth: Comparative evidence for sub-Saharan Africa. International Monetary Fund.

United Nations Secretary-General's High-Level Panel on Women's Economic Empowerment (2016). Leave No One Behind - A Call to Action for Gender Equality and Women's Economic Empowerment. UN 